\title{
A Comprehensive Perspective on Medical Tourism Context and Create a Conceptual Framework
}

\author{
Masoud lajevardi \\ PHD student in marketing management, Department of Management, Semnan Branch, Islamic Azad University, \\ Semnan,Iran
}

\begin{abstract}
This study developed a theoretical structural model to examine the influence of motivational factor and perceived destination image in the perceived service quality and overall satisfaction of medical tourists who have travelled to a foreign country to obtain a medical treatment. The theory of motivation, perception was combined in this research. This study included customer perceptions based on motivational factor, destination image, quality, value, and satisfaction which occurred after the medical trips. This is a quantitative study and survey method is used to collect data. The instrument of this study is developed based on the review of previous literature. There were only 260 completed responses that met all the required criteria. After data collection was completed, the Statistical Package for Social Sciences (SPSS) and SPSS AMOS 22.0 will be used to analyze and interpret the result. The results show that there were positive impact of Destination Image and Motivational Factor on Perceived Value, and positive impact of Perceived Value on Overall Satisfaction. Once again, it can be confirmed that Destination Image has the strongest impact on Perceived Quality, illustrated by the highest standardized value of 473 .
\end{abstract}

Keywords: medical tourism, motivational factor, perceived destination image, perceived service quality

\section{Introduction}

Medical tourism as a niche has emerged from the rapid growth of what has become an industry, where people travel often long distances to overseas countries to obtain medical, dental and surgical care while simultaneously being holidaymakers, in a more conventional sense. Medical tourism is becoming an increasingly popular option for patients looking to access procedures (typically via out-of-pocket payment) that are seemingly unavailable to them in their home countries due to lack of affordability, lack of availability, and/or lengthy waiting lists, among other reasons (Ackerman, 2007). People wishing to access procedures such as cardiac, orthopedic, dental, and plastic surgeries are going to key destination countries known to provide care for international patients (Al-Hinai et.al, 2011). Medical tourism enables patients to quickly and conveniently receive medical services through travel, at lower prices and, oftentimes, at better quality than they could in their native countries. The reasons patients travel for treatment vary. For example, In Canada, people are frustrated by long waiting lines. In Great Britain, patients cannot wait for treatment by the National Health Service; nor can they afford to see a physician in private practice. (Allemanet.al, 2011)

Medical tourism combines medicine with tourism, encouraging patients to seek medical services while traveling for relaxation and leisure and have emerged as one of the fastest growing areas of academic research interest in both tourism and health studies (Balaban and Marano, 2010; Crooks et al., 2010; Underwood and Makadon, 2010; Whittaker, 2008). Smith and Puczko (2009) argue that health tourism is composed of medical tourism and wellness tourism, meaning that medical tourism is a subset of health tourism. Borman (2004) and Jonathan (1994) define health tourism as attracting tourists with the unique attractions of the destination combined with facilities for healthcare services. Connell (2006) points out that a distinction must be made between health tourism and medical tourism, whereby medical tourism is the correct term to use in cases in which medical interventions are required. Medical tourism involves not only going overseas for medical treatment, but also the search for destinations that have the most technical proficiency and which provide it at the most competitive prices (Augé, 1995). The degree of synthesis between medical services and tourism is also significant, in that medical tourism's fundamental characteristic is its combination of medical services and the tourism industry. As a result, the degree of synthesis between these two areas should be taken into consideration when defining medical tourism. However, some researchers in medical journals state that medical tourism includes only medical services, rather than tourism services (Bagheri, 2010). Within the health tourism arena, medical tourism is among the fastest growing sectors, and many countries are now making legal and practical plans to serve it reduced transportation costs, higher incomes, knowledge and technology transfer, and competitive prices all favor travel to distant countries for medical reasons. One of the fastest growing tourism markets in the world, medical tourism now generates US\$60 billion in business annually worldwide (Bell et.al, 2011), and the number of countries offering state-of the- art medical facilities and services to foreign tourists is on the increase. This international trade in medical services also has huge economic potential for the global economy (Bookman \& Bookman, 2007), and medical tourism is emerging as a particularly lucrative sector for developing countries. 
Many countries have seized the business opportunities that medical tourism offers. In 2005, for example, India, Malaysia, Singapore, and Thailand attracted more than two and a half million medical tourists (Brown, 2008). Colombia, Singapore, India, Thailand, Brunei, Cuba, Hong Kong, Hungary, Jordan, Lithuania, Malaysia, the Philippines, and the United Arab Emirates have emerged as major healthcare destinations, and Argentina, Bolivia, Brazil, Costa Rica, Mexico, and Turkey are also in the process of making themselves attractive such destinations, particularly in the area of cosmetic surgery (Buzinde, 2012). At present, Asia constitutes the most important medical tourism region. Horowitz and Rosenweig (2007) has summarized that major reasons for seeking medical tourism are (1) low cost, (2) avoid waiting lists, (3) procedure not available in home country, (4) tourism and vacations, (5) privacy and confidentiality. While people from less developed countries have often visited, and continue to visit, developed countries such as US and UK to avail of cutting -edge medical facilities and highly skilled physicians, this trend began to reverse in the 1990s and the term medical tourism came to refer to people from developed countries travelling to emerging economies with the intention of combining health care with holidaying. With the aging population demographic in developed countries that increases demand, and the shortage of trained doctors (Carrera andBridges , 2006), leading to increasing health care costs results in an unfulfilled demand for medical services, a gap occurs, one that several countries seek to fill. According to World Health Organization (WHO), in 2000, U.S. spent 13.2 percent of the GDP on its health care, by the 2007 this went up to 15.7 percent (WHO, 2010), and is estimated to be $19.3 \%$ by 2019 . Asia, widely considered the region with the most potential in the world medical tourism market, generated \$3.4 billion in revenue in 2007 through medical tourism. Asia's revenues have increased annually by more than $20 \%$, and are expected to total $\$ 4.4$ billion by 2012 . In 2003 , approximately 350,000 patients from industrialized nations traveled to less developed countries for healthcare. It is projected that 750,000 Americans will go offshore for medical care in 2007. Medical tourism in Asia is currently generating US\$ 1.3 billion in revenue and is expected to grow to US\$ 4.4 billion by 2012. In today's highly global competitive environment, a number of countries, such as Belarus, Latvia, Lithuania, Costa Rica, India, Malaysia, Singapore and Thailand, have responded to the opportunities offered by medical tourism to provide cross-border medical care for international visitors (Chee, 2010). In India Medical tourism is one of the fastest growing subsectors of its industries. Surgical procedures that can cost hundreds of thousands of dollars in the USA can be had at a fraction of the cost in India. The total healthcare market in India is expected to increase its contribution to GDP from 5.2 percent at present to 8.5 percent over the next ten years News from India Tourism Report (2010). Connell 2006 state that, India advertises itself as the global center of medical tourism by offering everything from alternative Ayurveda therapy to coronary bypasses and cosmetic surgery. Travel companies in India are also cooperating with hospitals to facilitate travel by arranging phone consultations with doctors to help foreign patients save time and money once they get to India. Thailand has the longest history; it became notable as a destination for medical tourism as early as the 1970s when the medical tourism profession began to specialize in sex change operations; later they moved to cosmetic surgery. Medical tourism in Thailand is now a prosperous industry. In 2007, as many as 1.4 million visitors arrived in Thailand seeking medical care; the Health Ministry expects the number of medical tourists to surpass two million by 2012 Report from Airline \& Travel News (2009). To build brands in the healthcare industry, leading hospitals in Thailand have spent the last decade striving to be the biggest and best in the world. They have recruited not only experienced doctors but also embraced foreign management expertise. Singapore, whose global reputation as a medical tourism center has sought to compete with Thailand. Most of the private hospitals in Singapore are participating in the medical tourism program; some of these hospitals have gained international health accreditation from the Joint Commission International (JCI) of the USA. The government has made various efforts to promote healthcare services for the benefit of the medical tourism industry. Malaysia is getting a reputation as one of the preferred locations for medical tourists on account of its excellent and efficient medical staff, as well as advanced healthcare and wellness facilities (Cohen, 2008). Dubai has just built Healthcare City in an attempt to capture the Middle Eastern market and divert it from Asia; the country also plans to include a branch of Harvard Medical School within the Healthcare City, which will make it one of the most prestigious foreign healthcare facilities outside of the west. The main medical treatments offered by Dubai include cochlear implants, diabetes treatments, orthopedics, cardiology, cosmetic surgery and lung treatments Report from medicaltourism.com (2012). Several countries in Central and South America also developed strong reputations for cosmetic and plastic surgery, bariatric procedures and dental care.

The medical tourism issue has been taken into consideration during recent years In Iran. The special position of Iran's geographical location, its history of medical science and existence of expert medical and paramedical workforce, low costs and high quality of its health services, all could increase the importance of medical tourism in economic and medical fields in this country. Considering that the researches on medical tourism issue are sparse in Iran and this subject has a high position of importance, analyzing its current situation could be useful for making decisions about identification and improvement the areas which are in a high priority, reinforcement of this industry's potentials and finally, attracting more medical tourists. Nowadays, many Asian countries such as Iran, with a high potential for attracting medical tourism have sought to enter the market. Iran 
offers a wide range of state-of-the-art treatment, through an extensive network of highly-equipped hospitals, around 850 hospitals, and rehabilitation centers at reasonable costs. An analysis of the costs of the various procedures shows that treatment costs in Iran are much lower as compared to the developed countries. Iran is also very cost competitive as compared to its regional competitors, including Jordan, Turkey, UAE, Saudi Arabia, and Bahrain as well as southeast Asian countries such as Thailand, Singapore, Malaysia, Philippines, and India. The unique combination of experience, facilities and natural resources is the key to success of the Iranian health care system. Apart from these, Iran also enjoys a unique range of competent medical staff. Medical specialists and sub-specialists in the country are highly-qualified professionals and are supported by well-trained paramedics and sophisticated medical equipment. The nursing service in Iran is also highly qualified. Further, the Iranian health care system is constantly supported by extensive medical research. Iran has a unique combination of healthy and pleasant climate, wonderful scenery, magnificent historical and cultural monuments as well as cutting edge technology and sophisticated medical equipment. Before the advent of medical tourism, as we know it today, Iran was known as a destination for treatment of Muslims, attracting thousands of visitors from Persian Gulf countries. Today, medical tourism in Iran is an emerging cluster aiming to provide world-class medical facilities by public-private partnership. While historical data on medical tourism is limited, according to the government, in 2007, there were over 50,000 non-resident patients. Iran has been assembling the various factor inputs necessary for thriving medical tourism cluster. Such factors can be broadly classified as: (1) suitable infrastructure, (2) nice environment, people and culture, and (3) government's key policy. In terms of human resources, Iran has highly competent medical practitioners. The country now has over 850 hospitals nationwide. Hospitals in Iran utilize modern technology. However, the use of modern medical technology, especially high-tech medical equipment, is centered primarily in big cities and private hospitals. Public hospitals do not get involved in medical tourism. In terms of international airports, further investments are needed to improve the quality of infrastructure. Iran has a healthy and pleasant climate, wonderful scenery, and unrivaled historical and cultural monuments. The country is rich in natural resources of spas and hot springs in different cities. This is complemented by internationally recognized warm hospitality of the Iranian people. However, there are some limitations, including: administrative "red tape" in issuing practicing licenses, very limited malpractice insurance and a lack of proficiency in English or other languages in the country. In 2012 Iran launched new plans to expand medical tourism in the region. The Health Tourism Iran hosted 200,000 health tourists in 2012, earning \$1.5 billion, a figure more than double 2011. Last year, more than 4.5 million foreign tourists spent $\$ 9$ billion in Iran and created jobs for 2.5 million people directly or indirectly. Iran's Cultural Heritage, Handicrafts and Tourism Organization (ICHHTO), has conducted studies that suggest the best targets are Iraq, Afghanistan, Persian Gulf states, Central Asian nations and Iranians residing abroad.

The results of analysis of 240 articles related to medical tourism context reveal that since, lot of research about factors (motivations) affecting patient destination choice has been conducted. These researches presented a sporadic classification of motivations. Furthermore, some researches focused on pull and push factor on destination choice behavior. (Grail Research, 2009; Ye et al. 2008; Hong et al. 2007; Ehrbeck, Guevara, \& Mango, 2008; Marlowe \& Sullivan, 2007; Conell, 2006; Deloitte, 2009; Forgione \& Smith, 2007; Heung, Kucukusta, \& Song, 2010; Ye et al. 2010; Leng, 2007; Howze, 2007; Garcia, 2005; Burkett, 2007; Kangas, 2007, Horowitz and Rosensweig, 2007; Gray and Poland, 2008; Lunt and Carrera, 2010; Balaban \& Marano, 2010; Glinos et al. 2006; Connell, 2006; de Arellano, 2007; Turner, 2007; Hall, 2011; Dunn ,2007; Blesch, 2007; Palvia, 2007; Hudson, 2009; Bookman \& Bookman, 2007; Steiner, 2010).

As above aforementioned, at the first, this research attempt to presenting a coherent classification of medical tourist motivations that divided those to three categories named: medical-orientation, tourismorientation and religious-cultural orientation.

This study developed a theoretical structural model to examine the influence of motivational factor and perceived destination image in the perceived service quality and overall satisfaction of medical tourists who have travelled to a foreign country to obtain a medical treatment. The theory of motivation, perception was combined in this research. This study included customer perceptions based on motivational factor, destination image, quality, value, and satisfaction which occurred after the medical trips. The results show the appropriate measurement model form confirmatory factor analysis and structural model form structural equation modeling. In addition, causal linked between constructs presents some significant relationships among four constructs

\section{Literature review, Conceptual framework and hypothesis Medical tourism}

Medical tourism is not a new concept. In ancient times people travelled to various spas, hot springs, and rivers seeking cures and/or rejuvenation. Moreover, Medical tourism burst onto the global scene in the days of classical Greece when Greek pilgrims used to travel from various places throughout the Mediterranean to a small territory in the Saronic Gulf called Epidauria (Connell, 2006). The globalization of health care has given rise to a new form of tourism that is commonly known as health tourism. Within the health tourism arena, medical tourism is 
among the fastest growing sectors, and many countries are now making legal and practical plans to serve it (Connell, 2008). More recently, people from developing countries have travelled to developed countries seeking more sophisticated medical treatment. However, the contemporary trend is now in the opposite direction as an increasing number of patients from developed countries travel to developing countries to receive medical treatment. The medical tourism industry has been estimated to be a $\$ 60$ billion industry, and despite the global economic slowdown, is expected to grow at a rate of up to $35 \%$ in coming years. Furthermore, Medical tourism has been developing rapidly in many countries and regions such as India, Thailand, Singapore, and Taiwan. For example, in 2006, there were 410,000 medical tourists visiting Singapore, which generated around USD 900 million. Finally, The market for medical tourism is projected to explode from three quarter million travelers in 2007 to 23 million by 2017 , at which time spending on medical tourism is expected to reach US\$79.5 billion per year (Connell, 2011).

Bookman and Bookman (2007) identify three forms of medical tourism: invasive, diagnostic and lifestyle. Invasive treatments involve high-tech procedures performed by a specialist; diagnostic procedures encompass several types of tests such as blood screenings and electrocardiograms; and lifestyle includes wellness or recuperation treatments.

There is four mode model of medical tourism in USA.

Mode 1: Direct medical tourism. Consumers who use this mode are familiar with a foreign hospital and make their own arrangements for travel and medical treatment. This is the simplest and earliest mode of medical tourism.

Mode 2: Medical tourism arranged by medical tourism facilitators (MTFs). This mode represents consumers who use the services of agencies that specialize in locating suitable foreign hospitals and arranging treatment, transportation, and lodging during recuperation.

Mode 3: Medical tourism induced by US health plans or by US employers. As the availability of medical care in foreign hospitals has become more widely recognized and in an effort to contain cost, some employers and insurance companies have started to provide incentives for covered employees to seek medical care outside the USA. Similarly, some managed-care health plans have included foreign hospitals on their lists of approved providers as a way to reduce costs.

Mode 4: Medical tourism encouraged by US healthcare providers (DHP). This is an extension of the common practice of hospitals outsourcing medical services. At the time of writing, there are only a small number of anecdotal instances of this occurring, but as more US hospitals partner with foreign hospitals, as after care is gaining its well-deserved attention in medical tourism, and as consumers become more accustomed to these partnerships, this mode may grow in importance. Some US healthcare providers with international presence are already sharing their management protocols with FHPs (H\&HN, 2004).

The idea of traveling around the world for medical treatment has captured the attention of much of the academic press (Balaban and Marano, 2010; Bookman and Bookman, 2007; Connell, 2006). Regarding medical tourism, various definitions has been proposed (see table 1).

Some Terms such as medical travel, medical tourism and health tourism are generally employed to conceptualize the meaning of traveling to another place for health care. For example, a recent study conducted by Ehrbeck et al. (2008) strictly defined medical travelers as people whose primary purpose in traveling is medical treatment in a foreign country. This definition eliminates the following classes of people: ordinary tourists who suddenly become sick; wellness tourists who travel for massages or acupuncture; expatriates who seek care in their country of residence; and patients who travel in largely contiguous geographical areas to the closest available care. Furthermore, Medical tourism has emerged from the broader notion of health tourism. Some researchers have considered health and medical tourism as a combined phenomenon but with different emphases. Carrera and Bridges 2006, identify health tourism as the organized travel outside one's local environment for the maintenance, enhancement or restoration of an individual's well-being in mind and body. It encompasses medical tourism which is delimited to organized travel outside one's natural health care jurisdiction for the enhancement or restoration of the individual's health through medical intervention. Past research (Cook, 2010) has defined health tourism as the promotion by a tourist destination of its health facilities and services. While Bookman and Bookman (2007) suggested that in recent usage medical and health tourism both refer to the sale of high-tech medical care to foreigners. 
Table 1. Definitions Regarding medical tourism

Medical In its broadest conceptualization, medical tourism refers to travel with tourism the express purpose of obtaining health services abroad

Connell, 2006

\begin{tabular}{|c|c|c|}
\hline tourism & the express purpose of obt & 2007 \\
\hline $\begin{array}{l}\text { Medical } \\
\text { tourism }\end{array}$ & $\begin{array}{l}\text { From a destination perspective, medical tourism can be defined as the } \\
\text { offshore provision of medical services, in combination with other } \\
\text { conventional tourism products, by leveraging a comparative cost } \\
\text { advantage. }\end{array}$ & $\begin{array}{l}\text { Awadzi and Panda, } \\
2005 \\
\text { Percivil and Bridges, } \\
2006\end{array}$ \\
\hline $\begin{array}{l}\text { Medical } \\
\text { tourism }\end{array}$ & $\begin{array}{l}\text { Travel activity that involves a medical procedure or activities that } \\
\text { promote the wellbeing of the tourist }\end{array}$ & Lee \& Spisto, 2007 \\
\hline $\begin{array}{l}\text { Medical } \\
\text { tourism }\end{array}$ & $\begin{array}{l}\text { Medical industry practitioners have defined medical tourism as the act } \\
\text { of travelling beyond a home country to receive a health care treatment } \\
\text { that is either less expensive or more accessible }\end{array}$ & $\begin{array}{l}\text { Kim, Leong, Heob, } \\
\text { Anderson, \& Gaitz, } \\
2009\end{array}$ \\
\hline $\begin{array}{l}\text { Medical } \\
\text { tourism }\end{array}$ & $\begin{array}{l}\text { An economic activity that entails trade in services and represents the } \\
\text { splicing of at least two sectors: medicine and tourism }\end{array}$ & $\begin{array}{c}\text { Bookman \& } \\
\text { Bookman's ,2007 }\end{array}$ \\
\hline $\begin{array}{l}\text { Medical } \\
\text { tourism }\end{array}$ & $\begin{array}{l}\text { Set of activities in which a person travels often long distances or across } \\
\text { the border, to avail medical services with direct or indirect engagement } \\
\text { in leisure, business or other purposes. }\end{array}$ & Jagyasi, 2009 \\
\hline $\begin{array}{l}\text { Medical } \\
\text { tourism }\end{array}$ & $\begin{array}{l}\text { Defined medical tourism as travel for recovery, instead of travel for } \\
\text { direct treatment }\end{array}$ & Hunter-Jones ,2005 \\
\hline $\begin{array}{l}\text { Medical } \\
\text { tourism }\end{array}$ & $\begin{array}{l}\text { Medical tourism is understood as foreign travel for the purpose of } \\
\text { seeking medical treatment with or without the consumption of tourism } \\
\text { services }\end{array}$ & $\begin{array}{l}\text { Balaban and Marano, } \\
2010 \\
\text { Connell, } 2006\end{array}$ \\
\hline
\end{tabular}

\begin{tabular}{|llcc|}
\hline $\begin{array}{l}\text { Medical } \\
\text { tourism }\end{array}$ & $\begin{array}{l}\text { Described medical tourism as the activity of patients who go abroad to } \\
\text { seek healthcare because of some relative disadvantage in their own } \\
\text { national healthcare system }\end{array}$ & $\begin{array}{c}\text { Glinos and } \\
\text { Baeten ,2006 }\end{array}$ \\
\hline $\begin{array}{l}\text { Medical } \\
\text { tourism }\end{array}$ & $\begin{array}{l}\text { Residents seeking medical, dental, and cosmetic surgeries (both } \\
\text { elective and non-elective) from healthcare providers outside their home } \\
\text { countries. }\end{array}$ & $\begin{array}{c}\text { Gan and Frederick } \\
2011\end{array}$ \\
\hline
\end{tabular}

\begin{tabular}{|c|c|c|}
\hline $\begin{array}{l}\text { Medical } \\
\text { tourism }\end{array}$ & $\begin{array}{l}\text { Medical tourism refers to travel for the purpose of obtaining medical } \\
\text { services in a foreign country where medical technology is advanced as } \\
\text { well as affordable, it also encompasses activities such as the intentional } \\
\text { marketing of medical services and facilities to foreign patients }\end{array}$ & Bies \& Zacharia, 2007 \\
\hline $\begin{array}{l}\text { Medical } \\
\text { tourism }\end{array}$ & $\begin{array}{l}\text { Traveling to a destination in another country to receive medical, dental } \\
\text { and surgical care because the destination enables better access to care, } \\
\text { provides higher quality care or offers the same treatment at a more } \\
\text { affordable price }\end{array}$ & Grail Research, 2009 \\
\hline $\begin{array}{l}\text { Medical } \\
\text { tourism }\end{array}$ & $\begin{array}{l}\text { Medical tourism as tourism where a person chooses to seek disease } \\
\text { prevention or treatment, or to enhance physical and psychological well- } \\
\text { being in a country other than their own. }\end{array}$ & $\begin{array}{l}\text { Hong, Lim, and } \\
\text { Kim ,2007 }\end{array}$ \\
\hline
\end{tabular}


Medical tourism programs are products where excellent medical service is combined with tourism and provided to foreign visitors, earning foreign revenue and developing related industries in addition to those normally developed by travel for leisure (Cormany and Baloglu , 2011). There are numerous definitions of tourists. For example authors as Gonzales, Brenzel and Sancho (2001) for instance, define medical tourists as people traveling to another country specifically to consume health care services, without even making reference to touristic activities. However, it is accepted that tourists are travellers who have travelled and stayed away from their home environment for 24 hours or more, and hence, have often utilized some form of accommodation facility. Those travellers who do not meet this 24 hour criterion are generally referred to as 'visitors'. For travellers that travel overseas for medical purposes, conceptually, they would meet the definition of a tourist. Since medical tourists are travelers whose main motivation for travel is for a specific purpose, medical tourists can be categorized as a group of special interest tourists, hence participating in a form of special interest tourism (Crooks et.al, 2011). Medical tourism does not refer to care given when one happens to have a health emergency while abroad, as intent is key: the patient must actually intend to go elsewhere for care. Engaging in tourist activities, such as recovering in resorts in destination countries, is a common part of the medical tourism experience (Dalstrom, 2012). Moreover, People who become ill or injured while traveling abroad and require hospital care are not thought to be medical tourists, nor are expatriates accessing care in the countries or regions in which they live.

As mentioned before and For the purpose of this paper For the purpose of this paper medical tourism will be defined using the Medical Tourism Association's definition: Medical Tourism is where people who live in one country travel to another country to receive medical, dental and surgical care while at the same time receiving equal to or greater care than they would have in their own country, and are traveling for medical care because of affordability, better access to care or a higher level of quality of care (Deloitte, 2009). With today ${ }^{\text {ee }} \mathrm{s}$ technologies, such as the Internet, mobiles (Smartphones), iPads, the marketplace of medical tourism has become reachable for patients anywhere in the world. King (2009) describes the marketplace as a location where buyers and providers agree on a transaction to occur; medical tourism services can be reached by patients through alternative resources: through their own initiative and research on communication technologies (internet), or with the help of travel agencies which provide facilitators who select the most appropriate medical destinations. However, with today's technology, patients can learn about thousands of medical facilities and opportunities around the world, allowing them to make comparisons and choices based on the most efficient medical facilities that best suit their specific needs (Edelheit, 2008).

\section{Definitions of medical tourism}

Terms such as "medical travel," "medical tourism," "health tourism" and "patient mobility" are generally employed to conceptualize the meaning of traveling to another place for healthcare. For example, a recent study conducted by Ehrbeck et al. (2008) strictly defined medical travelers as people whose primary purpose in traveling is medical treatment in a foreign country. Past research (Ehrbeck et al, 2008) has defined health tourism as the promotion by a tourist destination of its health facilities and services. Laws (1996) asserted that health tourism means leisure away from home, with one of the purposes being to promote one's state of health; similarly, Hall (2003, p. 274) defined health tourism as "a commercial phenomenon of industrial society which involves a person traveling overnight away from the normal home environment for the express benefit of maintaining or improving health."

Medical tourism is not a new concept. In ancient times people travelled to various spas, hot springs, and rivers seeking cures and/or rejuvenation. More recently, people from developing countries have travelled to developed countries seeking more sophisticated medical treatment. However, the contemporary trend is now in the opposite direction as an increasing number of patients from developed countries travel to developing countries to receive medical treatment. Lee and Spisto (2007) have defined medical tourism in a simple context as a "travel activity that involves a medical procedure or activities that promote the well-being of the tourist". The most appropriate definition for medical tourism, illustrated by Bookman and Bookman "s $(2007$, p. 1) study, claims that it is "an economic activity that entails trade in services and represents the splicing of at least two sectors: medicine and tourism". Jagyasi (2008) has defined the two terms "tourism" and "medical" individually in order to establish a suitable definition for medical tourism. In this sense, medical tourism can be defined as a "set of activities in which a person travels often long distances or across the border, to avail medical services with direct or indirect engagement in leisure, business or other purposes" (Erbe, 2011). Regarding medical tourism, various definitions have been proposed. Hunter-Jones (2005) defined medical tourism as travel for recovery, instead of travel for direct treatment, while Bookman and Bookman (2007, p. 1) suggested that in recent usage medical and health tourism both refer to "the sale of high-tech medical care to foreigners." Some scholars have argued that medical tourism is understood as "foreign travel for the purpose of seeking medical treatment" (Gill and Singh, 2011), with or without the consumption of tourism services. Additionally, Hall (2011) suggested that, as of late, medical tourism belongs within the overall context of health tourism. The medical 
tourism can be defined as "traveling to a destination in another country to receive medical, dental and surgical care because the destination enables better access to care, provides higher quality care or offers the same treatment at a more affordable price".

\section{Medical tourism in Iran}

Iran seems to be an ideal destination for health tourism. Affordability is another key factor bringing patients to Iran. Patients can undergo treatment, recover and enjoy a holiday in Iran for much less than what it would cost them for treatment in other countries. The medical service in Iran is cheap while the healthcare establishments are well equipped and professional. Currently 30,000 foreign patients who are most from the neighbor countries come to Iran to receive medical treatments. Medical Tourism in Iran has been patronized by tourists looking for critical medical treatment as well as by people in need of cosmetic and preventative care. (http://dreamofiran.com/dossiers/health-tourism-why-iran/). Thanks to its geographical position, the conditions in neighboring countries, economically reasonable prices and advanced medical facilities, Iran is gradually becoming a destination for Islamic and regional medical tourists. Hospitals in Iranian cities offer medical and health care services for foreign medical tourists, and for the Iranians who go to large cities from those parts of the country that lack such services. The existence of mineral fountains in many parts of the country, targets one market. Other markets include fertility treatment, stem cell treatment, dialysis, heart surgery, cosmetic surgery, and eye surgery. It also produces unique medicines such as the anti-AIDS drug IMOD, and other high-tech drugs.30, 000 medical tourists enter Iran annually, and economic surveys show that each medical tourist brings three times as much hard currency to the country than regular tourists. There are also some 200,000 health, wellness and spa tourists.

According to last statistics of statistical center of Iran about 120000 hospital bed and 4551 laboratories, 3042 rehabilitation center, 2293 radiology and imaging centers and 7601 pharmacy are providing health services in Iran. Medical tourism is not new phenomenon in the world as well as in Iran. In the past some people from neighbor countries especially from Arab countries of Persian Gulf came to Iran. In this area in the country, there are no exact statistics about medical tourists came to the country but some resources indicated about 17500 patients came to Iran in 2005. The most popular procedures which are demanded include: advanced treatments of cardiac treatments and surgeries, cosmetic surgeries, productivity treatments, organ transplant (CHN news). The main reasons of coming patient to Iran are: quality of health services and low cost of treatments and drugs in comparison with other countries of the region (Middle East and Middle Asia), access to advanced and new medical procedures, equipment and qualified professionals and medical staff, similarity of culture and language in some regions of Iran with neighboring counties such as Iraq, Azerbaijan and lack of some medical procedures, equipment, medical professionals and health infrastructures in those countries combined with natural attractions, ancient and historical buildings in famous cities of Iran. Despite of these factors and existence of some legal factors such as the 4th and at present 5th program of economic, social, cultural development of Iran, medical tourism in Iran has not developed yet and some hospitals and medical and health centers individually are working in the area of importing patients from foreign countries and provide health services for them and some patients come to Iran in a traditional way.

Iran, located in the Middle East, is surrounded by Muslim countries such as Iraq, Afghanistan, Pakistan, Turkey, and Azerbaijan, to name a few. The majority of Iran's population is Muslim of the Shi'a sect. Many natural tourist attractions, historical and archeological sites with more than 7000 years of urban settlements, in addition to famous cities that have rich Islamic and pre-Islamic cultural backgrounds such as Isfahan, Shiraz and Yazd are located in Iran (Zendeh Del, 2001). Moreover, many sacred places for Shi'a Muslims termed "Imam Zadeh" are located throughout Iran (Ministry of Culture and Islamic Guidance, 2003). Some authors investigated medical tourism in Iran and the results of demographical characteristics of their study show that, all respondents were Muslim couples, of which $64.2 \%$ were Iraqi, 17.9\% Afghan, 7.5\% Pakistani and 10.4\% were infertile couples from other countries. The majority were Shi'a (94\%) and the remainder (6\%) Sunni Muslims (three Pakistani and one Iraqi couple). A total of $82.1 \%$ of these couples entered Iran by land while the remaining $17.9 \%$ traveled by air. Only $6 \%$ of these couples encountered problems during their applications for a visa. Of couples, $71.6 \%$ rented houses during their treatment period, $16.4 \%$ of them stayed at hotels and the remaining $11.9 \%$ stayed with their Iranian resident friends or relatives. In addition, most Afghan couples mentioned that they were previously in Iran as social workers (11 out of 12). Finally, 32.8\% of males and 49.2\% of females had a high school diploma or below, whereas $67.2 \%$ of males and $50.8 \%$ of females were university graduates.

\section{Motivational factors}

Having been identified in previous research, challenge in the tourism market is that motivation need to be understood by diverse perspectives of features (Gilmartin and White, 2010). Therefore, tourist motivation is an important factor in explaining tourist behavior in relation to destination choice, relating to the needs, goals, and preference of the tourists (Glinos et al, 2010). Extensive previous research has widely accepted that the analysis 
of motivations is based on the two dimensions of push and pull factors (Goodrich and Goodrich, 1987). Accordingly, "push factors" refer to intangible and intrinsic desires of human beings, including the desire for escape, novelty seeking, adventure seeking, rest and relaxation, health and fitness, and socialization (Gupta, 2008). While "push factors" are the socio-psychological needs that encourage an individual to travel, "pull factors" are considered as the external forces from the attributes that attract a person to a specific destination and establish the actual specific destination choice. From previous study, "pull factors" have been defined in terms of both tangible and intangible features such as natural and historical attractions, physical environment, infrastructure, food, people, sport and recreation facilities (Wilson, 2011). In another explanation, pull motivations have been described as factors influencing when, where and how people travel (Helble, 2011). On the other hand, the main pull factor that lead medical tourists to look for treatment in less developed countries is the low cost treatment. In addition, affordable air travel and favorable exchange rates are viewed as reasons that pull tourists travel out of their countries for medical treatment (Connell, 2006). In a report from UNESCAP (2007), other important pull factors include the emergence of the state-of-the-art medical facilities in developing countries and the aftercare which is equal in terms of quality. Study of Chen, Prebensen, and Huan (2008) revealed in their study that relaxation, pursuing multiple activities, recreation, and enjoying nature are primary factors of tourists' travel motivation to a wellness destination. Push and pull factors determine not only customer's decision to travel but also the choice of destination. Uysal and Jurowski (1994) concluded in their research that there is a relationship between push and pull factors. The push-pull model is also supported by other researchers (Herrick, 2007). The concept of push and pull factors has been characterized as relating to two separate decisions made at two separate points in time - one focusing on whether to go or not, the other on where to go. In contrast to this opinion, other researchers have supported that push and pull factors should not be viewed as being totally independent of each other but rather as being related to each other. While internal forces push people to travel away, external forces of the destination pull them to choose that particular (Heung and Kucukusta , 2010).

\section{Perceived destination image}

The definition of destination image refers to the impressions that a person has about a place, and this is composed of beliefs, ideas, and prejudices (Higginbotham,2011). This definition relates to an individual, while other definitions acknowledge that destination images can be shared by a group of people. The impression will help tourists consider whether the destination matches their mental image and recreational demands. The concept of destination image was evolved from an organic image, through an induced image, to a complex image (Hopkinset al., 2010). These image phases were connected to the functions of promotion, which are informative, persuasive, and remaining. According to Gunn (1972), organic images deal with tourists' impression of a destination without visiting the place, and induced images relate to an image influenced by directed information form the tourism organization. In another research of Echtner and Ritchie (1993), the concept of destination image should be composed of individual attributes' perceptions as well as holistic impressions of the place. Therefore, it is possible to say that destination image involves the images of the individual elements or attributes that contribute to the tourism experience of tourists (Horowitz and Rosensweig , 2008). A number of tourism researchers have studied about the destination image construct and its influence on tourists' behavior, the travel selection process, and travel satisfaction (Horton and Cole, 2011).

\section{Perceived service quality}

In the research field of tourism, the quality of opportunity or performance, and satisfaction and quality of experience are clearly distinguished (Hunter and Oultram, 2010). Quality of performance refers to the attribute of a service which is mainly controlled by service suppliers. Specifically, it is the output of medical service providers at the destination (Reisman, 2010). Therefore, evaluations of the service quality are based on tourists' perceptions of the service performance of the provider. In the past two decades, the theory and practice of service quality has attracted considerable attention from both theoretical and practical knowledge (Parry, 2008). Perceived quality is defined as the consumer' judgment about the superiority or excellence of a product the degree and direction of discrepancy between customers' perceptions and expectations (Inhorn and Patrizio, 2009). A measurement tool called SERVQUAL was developed by Parasuraman et al. (1985) in order to evaluate service quality (Pollard, 2010). A 22-item instrument represents five dimensions by which consumers evaluate service quality: tangibility, reliability, responsiveness, assurance, and empathy(Sengupta, 2011). Reliability is considered as the most important dimension which concerns whether the outcome of service delivery was as promised, while the other four dimensions refer to the process of service delivery (Jones, 2011). However, it was very difficult to translate SERVQUAL to measure health care services due to the generic service quality dimensions. Hence, Jun, Peterson and Zsidisin (1998) narrowly focused on dimensions that are applicable to health care. The results of this study pointed out eleven dimensions: tangibles, reliability, responsiveness, competence, courtesy, communication, access, caring, patient outcomes, understanding patient, and collaboration 
(Thompson, 2011).

\section{Overall Satisfaction}

Previous literature has suggested that customer overall satisfaction with a hospitality experience is the sum of satisfaction with the individual elements or attributes $\mathrm{f}$ all the products and services that create the experience (Kangas, 2007). Therefore, when experiencing hospitality experiences, customers tend to form a set of independent impressions on each and compare those with the expectations of the same attributes. In a highly competitive market like medical tourism, sustainable competitive advantage is very important and dependent on the ability to deliver high service quality that will satisfy customers (Kangas, 2011). Customer satisfaction, in general, is a comparison between the expectation of value (before the purchase) and the perceived value (after the purchase). Baker and Crompton (2000) identified that satisfaction in tourism refers to the emotional state of tourists after exposure to the opportunity or experience. Since medical tourists are travelers who combine medical treatment and tourism together, Saiprasert (2011) suggested looking at the concept of "patient satisfaction" of health care industry. Linder-Pelz (1982) proposed five determinants of satisfaction in health care services: occurrences, value, expectations, interpersonal comparisons, and entitlement. In another study of Sitzia and Wood (1997), they classified four components of patient satisfaction in terms of accessibility, interpersonal aspects of care, technical aspects of care, and patient education/information. The result suggested that two strongest predictors of satisfaction were older age and better self-perceived health status at admission. The study of Thi, Briancon, Empereur, and Guillemin (2002) investigated seven satisfaction dimensions of in-patients receiving medical and surgical care from hospital. The seven dimensions are: admission, nursing and daily care, medical care, information, hospital environment and ancillary staff, overall quality of care and services, and recommendations (Veerasoontorn et al, 2011).

\section{Hypothesis development}

Applying the push and pull factors deriving from the motivational attributes, the perceived quality of medical treatment experience can be measured (Knudsen, 2011). According to a research of Crooks et al (2010), push and pull factors incorporate service quality attributes of the medical service providers at the destination, along with the destination perception, process of travel and medical tourism experience as a whole. Therefore, the following hypothesis is proposed:

H1: Motivational factors have significant effect on the perceived quality of the medical treatment at the destination.

Previous researchers have studied the influence of destination image on tourists' behavior, the destination selection process, and travel satisfaction (Laugesen and Vargas-Bustamante, 2010). In the tourism and marketing literature, destination image is positively related to the service quality at a sport event (Lee et al, 2012). This view is also supported by Chen and Tsai (2007) and Lee et al. (2005). These researchers stated that tourists having a favorable destination image would perceive their onsite experiences (perceive service quality, perceived value) positively, which then lead to higher satisfaction levels. In another research of Kotler, Bowen, and Makens (1996), they proposed the following sequence: image, quality, satisfaction. In this case, destination image could affect the way customers perceive quality. Moreover, previous literature also pointed out that destination image positively influences perceived quality and satisfaction because it creates expectations that individuals form before the visit (Lefebvre, 2008).

Another research (Lunt and Carrera., 2010) has indicated the influence of tourism image on consumer behavior. This study examined the relationship between destination image and perceived quality and customers' satisfaction. The results supported the view that image of destination is a direct antecedent of perceived quality, and satisfaction. The following hypothesis is proposed based on the discussion of previous literature of destination image and perceived service quality:

H2. Medical tourists' perceived destination image positively influences their perceived service quality of medical treatment.

Perceived service quality has been considered to be one of the critical antecedents of both satisfaction (Martin, 2009) and perceived value (Mazzaschi, 2011). The theoretical justification for the connection between perceived quality, perceived value and satisfaction is taken from a coping framework of Bagozzi (1992), in which he suggested that initial service evaluations lead to emotional reactions, thus in turn, drive consumer behavior. Previous literature, which has adapted Bagozzi's framework to the service context, suggest that higher performance-oriented service quality and value appraisals precede satisfaction (Moghimehfar and Nasr-Esfahani, 2011). Bolton and Drew (1999) developed a model of customers' assessments of service quality and satisfaction by using customers of telephone service. The study concluded that perceived service quality has an important direct effect on service value assessment, hence, directly affects the overall satisfaction of customers. In another research of McDougall and Levesque (2000), they investigated the relationship between service quality, perceived value and customer satisfaction in different areas: restaurant, dentist, and auto service. The result 
revealed that service quality was the most important drivers of customer satisfaction. A major conclusion of this study was that both perceived value and perceived service quality attributes should be incorporated into customer satisfaction models to explain a more complete picture of drivers of satisfaction. Baker and Crompton (2000) focused their study on quality, satisfaction and behavioral intentions of tourists. In this research, quality was conceptualized as the attributes of a service which were controlled by suppliers, while satisfaction referred to tourists' emotional state after experiencing tourism activities. The hypothesis of perceived quality would have strong effect on satisfaction and behavioral intentions was confirmed with the results. Petrick (2004) examined the relationships between satisfaction, perceive value, and quality in predicting cruise passengers' behavioral intentions. The three constructs have been examined from three different perspectives to assess which one best explained customers' intentions to repurchase. The results showed that quality was the best predictor of behavioral intentions with cruise passengers. However, in this study, it was found out that there was a correlation between perceived quality and satisfaction. Lee, Graefe, and Burns (2004) conducted a research on service quality and satisfaction on forest visitors. The study concluded that service quality is an antecedent of satisfaction and satisfaction had a moderate effect on forest visitors' behavioral intention. In a study on health care customer satisfaction (NaRanong and NaRanong, 2011), researchers proposed a relationship among service quality, value, patient satisfaction and behavioral intention. 537 responses were collected from South Korea medical consumers to analyze the model. Between two observed constructs (service quality and value), service quality appeared to be a more important determinant of patient satisfaction than value. Results also revealed that both service quality and value had significant effect on repurchase intention while value was influenced by perceived quality.

Based on the previous literature discussed above, the following hypothesis is proposed:

H3. Medical tourists' perceived quality positively influences their overall satisfaction of medical treatment at the destination.

The conceptual model concluded all the above hypotheses is presented in figure 1 as below:

Figure 1. Conceptual model

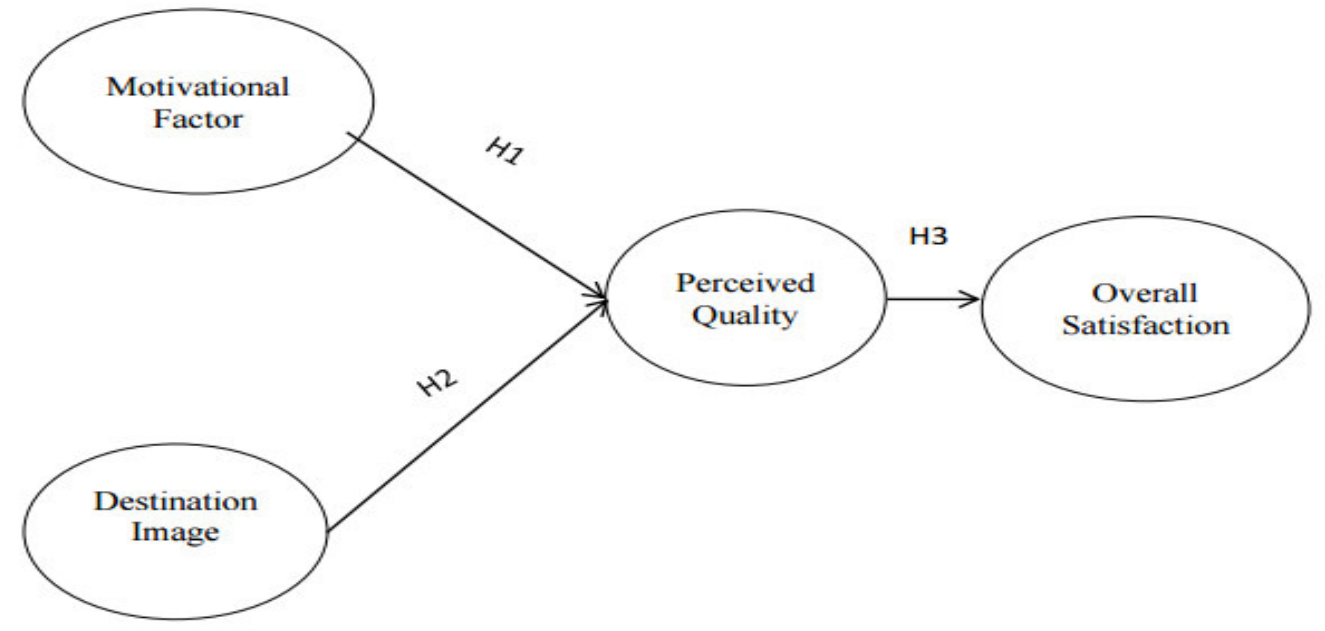

\section{METHODOLOGY}

This is a quantitative study and survey method is used to collect data. The instrument of this study is developed based on the review of previous literature on motivational factors, perceived destination image, perceived service quality, perceived value and overall satisfaction. Survey questionnaire is used as main data gathering instrument to test the reliability and validity of the conceptual model and research hypotheses. In instrument development stage, the related studies are searched for building construct measurement. The questionnaire consisted of five sections. The first section of the questionnaire collected information regarding to behaviors of medical tourists. The questions in this section include reason and type of medical treatment seeking, sources of information, frequency of travelling for medical tourism, medical insurance coverage, the destination traveled to for medical treatment, alternative choice of destination if considered, travel arrangement and approximately time to spend on medical tourism. Respondents were required to answer the entire question that was appropriate to their circumstance. The second section gathered information related to motivation factors and destination image. In this section, respondents were asked to rate their agreement on the different attributes of push and pull factors, as well as the perceived destination image. The 5-point Likert-scale ranging from "strongly disagree" to "strongly agree" was used in this section. 
Table 2. List of Motivational Factors and Perceived Destination Image Attributes

\begin{tabular}{|l|l|}
\hline Motivational Factors and Perceived Destination Image & Construct \\
Attributes & \\
\hline Taiting time for medical service & Push factor \\
Type of medical treatment that is not allowed & Push factor \\
Type of medical treatment not covered by medical insurance & Push factor \\
Push factor \\
Privacy and confidentiality & Push factor \\
Opportunity for person who has limited or no medical insurance & Push factor \\
Ease of visa procedures & Pull factor \\
Recognized hospital/medical facility reputation & Pull factor \\
High standard level of medical staff & Pull factor \\
Recognized, positive reputation of physicians & Pull factor \\
Western experienced/trained physicians & Pull factor \\
Ease of medical treatment arrangements & Pull factor \\
A great place for relaxation after medical treatment & Destination image \\
Political stability & Destination image \\
Variety of existing tourist attractions for recuperating patients & Destination image \\
Opportunity to combine medical service with a vacation & Destination image \\
Tourism safety from crime and/or terrorist attack & Destination image \\
Ease of travel arrangements & Destination image \\
Ease of lodging arrangements & Destination image \\
Ease of transportation & Destination image \\
Friendliness and helpfulness of the local people & Destination image \\
Ease of accessibility when travelling & Destination image \\
\hline
\end{tabular}

The third section explored respondents' perception of perceived quality of medical treatment after their medical tourism experience. The questions included medical and nonmedical related attributes such as hospital reputation and accreditation, physicians experience, medical services, medical equipment and amenities, hospital, appointment and reservation system, protection and liability. Participants were asked to rate attributes on a 5point Likert scale with the anchors of 1 = "Strongly disagree" and 5 = "Strongly agree".

The following table lists the categorized attributes of the perceived quality of medical treatment. 
Table 3. List of Perceived Service Quality Attributes

\begin{tabular}{|c|c|}
\hline Perceived Quality of medical treatment Attributes & Construct \\
\hline $\begin{array}{l}\text { Process for setting up the medical appointment was simple and } \\
\text { easy }\end{array}$ & Process \\
\hline $\begin{array}{l}\text { Medical records and information was easily assembled and } \\
\text { transmitted }\end{array}$ & Process \\
\hline Short waiting time for medical examination & Process \\
\hline $\begin{array}{l}\text { Physicians adequately explained condition, examination results, } \\
\text { and medical process }\end{array}$ & People \\
\hline Physicians allowed to ask questions, enough to clarify everything & People \\
\hline Hospital/medical facility had a strong concern for patient safety & Protection \\
\hline $\begin{array}{l}\text { Hospital/medical facility valued and respected patients' privacy } \\
\text { and confidentiality }\end{array}$ & Protection \\
\hline Payment procedure was quick and simple & Price \\
\hline Provided convenient transportation arrangements & Additional service \\
\hline Language interpretation service arrangement was provided & Additional service \\
\hline $\begin{array}{l}\text { Effective coordination of arrangements between patient involved, } \\
\text { hospital, third-party insurance companies, and/or other involved } \\
\text { businesses }\end{array}$ & Additional service \\
\hline Destination was a good place to relax after treatment & Additional service \\
\hline Destination was a good place for a vacation & Additional service \\
\hline Costs associated with medical treatment & Price \\
\hline
\end{tabular}

In the fourth section of the questionnaire, respondents were asked to measure attributes relating to overall satisfaction of medical treatment in the form of 5-point Likertscale. In the last section, the demographic information of the respondents was collected with the questions regarding to gender, age, marital status, occupation, annual income. This information was collected to fully understand the respondents' background, and to make comparisons among sample groups for further analysis. 
Table 4. Final Construct Measurement Scales

\begin{tabular}{|c|c|}
\hline Construct & Measurement \\
\hline \multicolumn{2}{|c|}{ MOTIVATIONAL FACTORS (MI) } \\
\hline MIF1 & Shorter waiting time - \\
\hline MF2 & Less expensive medical treatment. \\
\hline MF3 & Type of medical treatmeat that is not allowed. \\
\hline MF4 & $\begin{array}{l}\text { Type of medical treatment not covered by medical insurance in } \\
\text { your coumtry }\end{array}$ \\
\hline MF5 & Ease of visa procechures \\
\hline MF6 & Political stability \\
\hline \multicolumn{2}{|c|}{ DESTINATION RMAGE (DI) } \\
\hline DII & A great place for relaxation affer medical treatment \\
\hline DI2 & Positive reputation as a tourist destination \\
\hline DI3 & Variety of existing tourist attractions for recuperating patients \\
\hline DI4 & Opportumity to combine medical service with a vacation \\
\hline DI5 & Preference of privacy and confidentiality \\
\hline \multicolumn{2}{|c|}{ PERCEIVED QUAIIIY (PQ) } \\
\hline $\begin{array}{l}\mathrm{PQ} 1 \\
\mathrm{PQ} 2\end{array}$ & $\begin{array}{l}\text { Short waiting time for medical examination form the physician } \\
\text { The physicians adequately explained my condition, examination } \\
\text { results, and medical proces } 5\end{array}$ \\
\hline $\mathrm{PQ}_{3}$ & $\begin{array}{l}\text { The medical facility valued and respected patients' privacy, } \\
\text { confidentiality, and disclosure }\end{array}$ \\
\hline PQ4 & $\begin{array}{l}\text { Provided assistance with financial arrangements, such as: } \\
\text { advanced estimates for fees, deposits, and payments }\end{array}$ \\
\hline PQ5 & The payment procedure was quick and simple \\
\hline PQ6 & $\begin{array}{l}\text { The physicians allowed me to ask many questions, enough to } \\
\text { clarify everything }\end{array}$ \\
\hline \multicolumn{2}{|c|}{ OVERAII SATISFACTION (OS) } \\
\hline OS1 & $\begin{array}{l}\text { Owerall, I was satisfied with my medical treatment churing my trip } \\
\text { abroad. }\end{array}$ \\
\hline OS2 & $\begin{array}{l}\text { Overall, I was satisfied with the hospitalmedical facilities } \\
\text { services dhuing my trip abroad }\end{array}$ \\
\hline OS3 & $\begin{array}{l}\text { Overall, I was satisfied with the hospitality services (lodging, } \\
\text { uansportation, dining, tourism services) churing my trip abroad }\end{array}$ \\
\hline $\begin{array}{l}\text { OS4 } \\
\text { OS } 5\end{array}$ & $\begin{array}{l}\text { Overall, I was satisfied with my medical trip abroad } \\
\text { Overall, I was satisfied with the destination I traveled to for } \\
\text { medical treatment }\end{array}$ \\
\hline
\end{tabular}

\section{Data collection}

Online survey had been distributed to the participants via Qualtrics, an online survey research platform. This third-party data collection service looked for potential respondents that meet the criteria of the research: individuals must have been primarily living in their country at the time of their medical trip, and they must have travelled to a foreign country to obtain medical procedures. At the end of the data collection period, out of 500 individuals that Qualtrics screened, there were 400 qualified for this study. However, there were only 260 completed responses that met all the required criteria. The sample included individuals who travelled abroad for medical treatment.

\section{Data analysis techniques}

After data collection was completed, the Statistical Package for Social Sciences (SPSS) and SPSS AMOS 22.0 will be used to analyze and interpret the result. Descriptive statistics were initially conducted to provide an overview of the respondents. Secondly, the reliability check (Cronbach Alpha) was applied to the data of the main survey in order to conduct a preliminary test of the validity and reliability of the scales to measure the conduct. Thirdly, CFA (Confirmatory Factor Analysis) is conducted. Finally, SEM (Structural Equation Modeling) is applied to test the relations between latent, observed variables, and hypotheses (Hoyle, 1995).

\section{Result of descriptive statistics}

This survey was fairly distributed to both gender. Out of 260 respondents, $55.8 \%$ were male (145) and $44.2 \%$ were female (115). The sample of this study comprised of six different age groups, which the majority were respondents from 26 to 35 years old (42.3\%), followed by $22.3 \%$ of respondents between ages $36-45$. The smallest number of this sample belongs to people in the age group of 56-65 (6.5\%).Most of the respondents from this study were married (70\%), $21.9 \%$ were single, and only $8.1 \%$ were divorced. Professional/technical was the most common occupational group in this sample with the highest percentage of $30.8 \%$, followed by selfemployed (18.8\%), Government/military group had the lowest percentage of $1.9 \%$. 


\section{Descriptive statistics of factors}

The next two sections are going to give descriptive statistics of four factors of the proposed model to understand the relationship between independent variables and dependent variables.

\section{Independent variables}

The descriptive show customers' perception about factors that influence on perceived quality of medical treatment and the overall satisfaction of the medical tourists. Between two factors, perceived destination image has a higher average mean value of 4.02 ranging from 3.88 to 4.13 . The result shows that the motivational factor and destination image are relatively important to medical tourists when coming to choose a place for medical treatment. Between two independent variables (motivational factor and destination image), the average of destination image (4.02) is slightly higher than that of motivational factor (3.87); therefore, it is possible to say that customers might consider the factor of destination image more than motivation factor. Moreover, MF2 (less expensive price) has the highest mean (4.20) among all the variables, which means that customers perceived this factor as the most important one. In contrast, it is surprising that MF6 (political stability) received the lowest mean value among 260 medical tourists.

\section{Dependent variables}

With the average mean value of 4.19 , the result indicates a relatively important perception of medical tourists about the service quality at the destination. Respondents most agreed with factor PQ3 "value and respect patients' privacy, confidentiality, and disclosure", illustrated by the hight mean (4.30) among the group Participants were really satisfied with the medical procedures they received after the medical trip abroad. This can be explained by the extremely high mean value of all five factors (all higher than 4.0). Additionally, among five factors, OS1 "satisfied with medical treatment during the trip abroad" received the highest value. Therefore, it is possible to say that medical treatment is considered as the main purpose of the trip abroad and the most important factor when evaluating their satisfaction.

\section{Confirmatory factor analysis (CFA)}

The final result after running CFA is shown in the figure below:

Figure 2. Confirmatory Factor Analysis Result

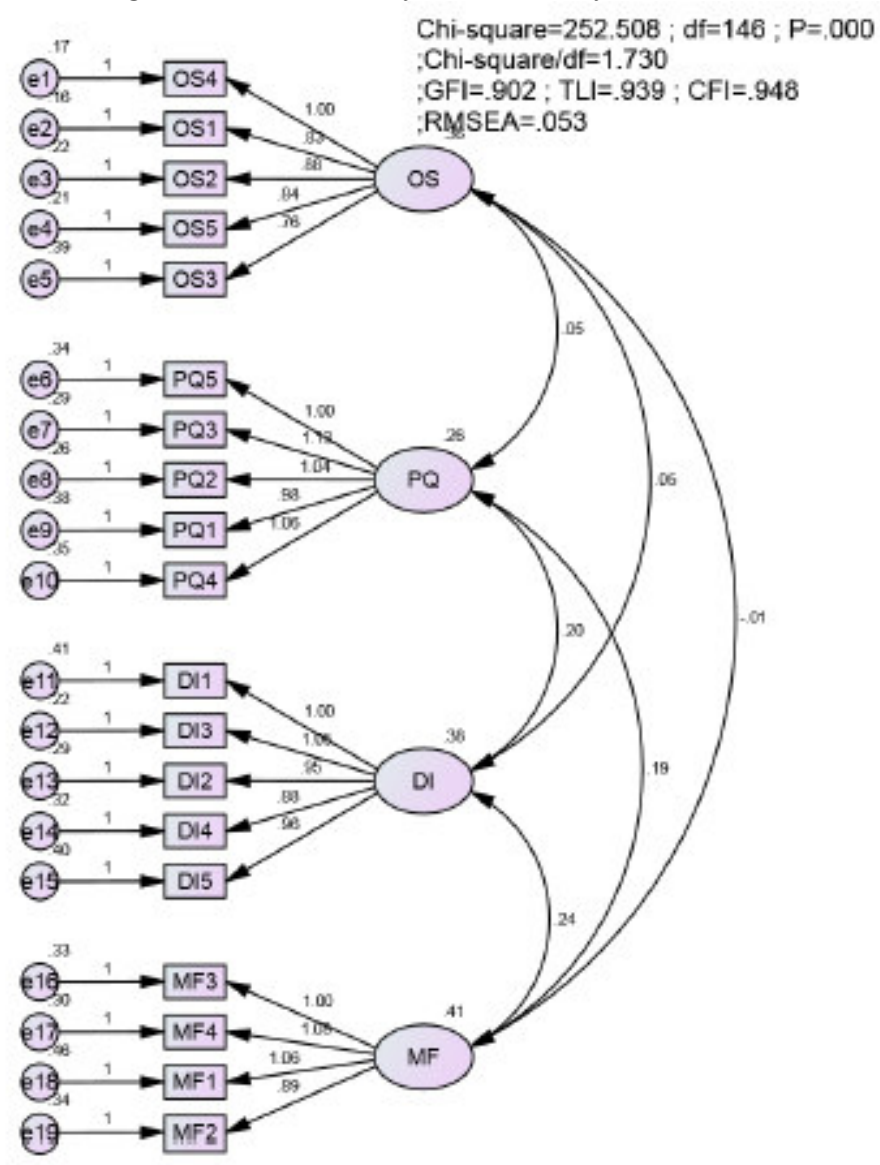


Table 5. Correlation

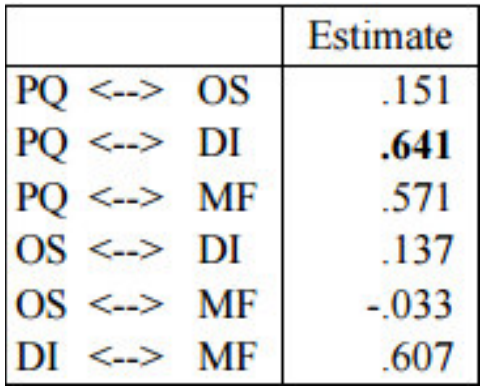

In order to create a model fit for the study, the CFA result value need to be compared with the threshold value mentioned above in Chapter 3. Base on the CFA result, all value is satisfied with the threshold.

Table 6. CFA result vs. threshold

\begin{tabular}{|l|l|}
\hline Threshold & CFA Result \\
\hline CFI $>=0.9$ & CFI $=0.948$ \\
\hline CMIN $/$ df $<=3$ & CMIN/df $=1.730$ \\
\hline RMSEA $<=0.08$ & RMSEA $=0.053$ \\
\hline Standardize Regression Weights $>0.5$ & All factors are greater than 0.5 \\
\hline
\end{tabular}

\section{Final model}

In the process of analyzing SEM, the first step was to assess the model fit using various measures-of-fit indices. The final SEM model was presented in the figure below.

Figure 3. Structural Equation Modeling Result

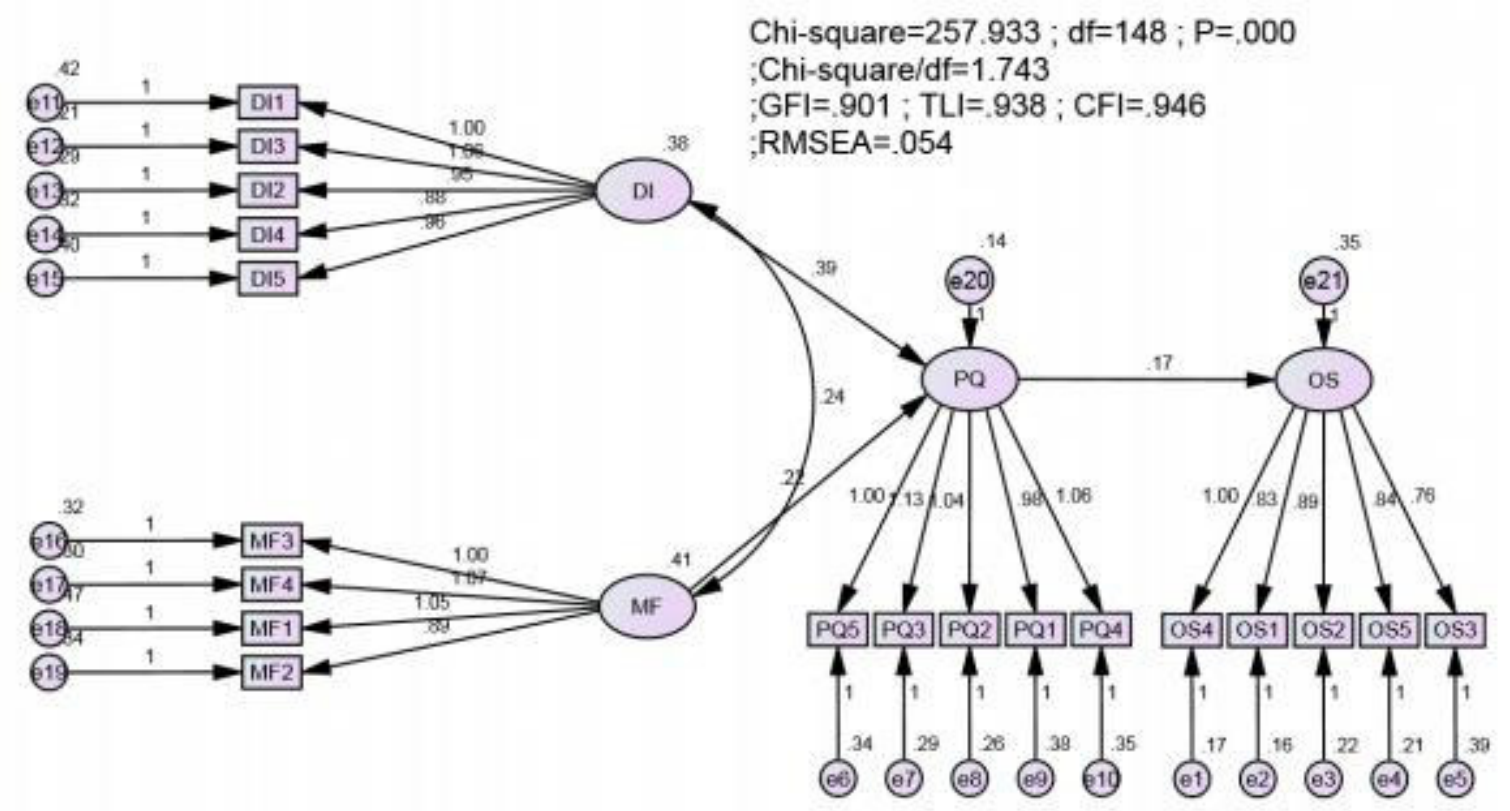

Table 7. Fit Statistics for Final Model

\section{Model Fit Statistics}

\section{$\begin{array}{llllll}\text { Chi-Sq }=258 & \text { df }=148 & \text { NFI }=0.883 & \text { CFI }=0.946 & \text { GFI }=0.901 & \text { RMSEA }=0.054\end{array}$}

According to the result from table 7, this model had a relatively good fit.

The regression weights table indicates that Destination Image, Motivational Factor have the $p$ value 
smaller than 0.05 . Therefore, we can conclude that these two factors have positive significantly impact on the Perceived Quality. Other than that, with a p value smaller than .05, Perceived Quality is proportionally positive influence factor towards Overall Satisfaction. It can also be concluded that with the estimate value of .373, Destination Image has the strongest influence on Perceived Quality, followed by the effect of Motivational Factor on Perceived Quality and Perceived Quality on Overall Satisfaction, illustrated by the regression weight estimated value of $.224, .170$.

\begin{tabular}{|c|c|c|c|c|c|c|c|}
\hline & & & Estimate & S.E. & C.R. & $\mathrm{P}$ & Label \\
\hline$\overline{\mathrm{PQ}}$ & $<-1$ & DI & .373 & .073 & 5.105 & $* * *$ & \\
\hline PQ & $<--1$ & MF & .224 & .071 & 3.163 & .002 & \\
\hline OS & $<-1$ & PQ & .170 & .085 & 1.994 & .046 & \\
\hline PQ5 & $<-1$ & PQ & 1.000 & & & & \\
\hline PQ3 & $<-1$ & PQ & 1.126 & .117 & 9.628 & $* * *$ & \\
\hline PQ2 & $<--1$ & PQ & 1.038 & .109 & 9.526 & $* * *$ & \\
\hline PQ1 & $<-1$ & PQ & .979 & .114 & 8.596 & $* * *$ & \\
\hline PQ4 & $<-1$ & PQ & 1.062 & .117 & 9.077 & $* * *$ & \\
\hline OS4 & $<-$ & OS & 1.000 & & & & \\
\hline OS1 & $<-$ & OS & .833 & .063 & 13.182 & $* * *$ & \\
\hline OS2 & $<--$ & OS & .887 & .071 & 12.491 & $* * *$ & \\
\hline OS5 & $<-$ & OS & .838 & .068 & 12.260 & $* * *$ & \\
\hline OS3 & $<-$ & OS & .764 & .081 & 9.460 & $* * *$ & \\
\hline DI3 & $<-1$ & DI & 1.000 & & & & \\
\hline DI1 & $<--1$ & DI & .947 & .083 & 11.365 & $* * *$ & \\
\hline DI2 & $<--1$ & DI & .902 & .074 & 12.232 & $* * *$ & \\
\hline DI4 & $<-1$ & DI & .835 & .073 & 11.445 & $* * *$ & \\
\hline DI5 & $<--1$ & DI & .908 & .081 & 11.221 & $* * *$ & \\
\hline MF3 & $<-1$ & MF & 1.000 & & & & \\
\hline MF2 & $<-1$ & MF & .889 & .086 & 10.373 & $* * *$ & \\
\hline MF4 & $<--1$ & MF & 1.072 & .093 & 11.474 & $* * *$ & \\
\hline MF1 & $<--1$ & MF & 1.051 & .101 & 10.413 & $* * *$ & \\
\hline
\end{tabular}

The effect of the dependent variables on the independent variables in this research can also be explained by standardized regression weights. Standardized regression weights present the standardized estimate value of the impact of Destination Image and Motivational Factor on Perceived Quality and Overall Satisfaction. The standardized values are all positive, therefore, there were positive impact of Destination Image and Motivational Factor on Perceived Value, and positive impact of Perceived Value on Overall Satisfaction. Once again, it can be confirmed that Destination Image has the strongest impact on Perceived Quality, illustrated by the highest standardized value of .473 .

\section{Hypotheses results:}

According to the results concluded from SEM, the proposed Hypotheses are answered as following:

Table 9. Hypotheses result

\begin{tabular}{|c|c|c|c|c|c|c|}
\hline & & Path Coef. & $\begin{array}{l}\text { Standard } \\
\text { Error }\end{array}$ & t-value & p-value & Results \\
\hline HI & $\begin{array}{l}\text { Motivational Factors } \\
\text {-> Perceived Quality }\end{array}$ & 0.224 & 0.071 & 3.163 & 0.002 & Supported \\
\hline $\mathrm{H} 2$ & $\begin{array}{l}\text { Destination Image -> } \\
\text { Perceived Quality }\end{array}$ & 0.373 & 0.073 & 5.105 & $<0.001$ & Supported \\
\hline H3 & $\begin{array}{l}\text { Perceived Quality -> } \\
\text { Overall Satisfaction }\end{array}$ & 0.170 & 0.085 & 1.994 & 0.046 & Supported \\
\hline
\end{tabular}




\section{Discussion and conclusion}

Hypothesis 1 proposed a relationship between motivational factors and customers 'perceived quality of medical treatment at the destination. The standardized path coefficient of the relationship between motivation factors and perceived quality was $(\mathrm{p}<.005)$ which indicated that motivation was a significant predictor of medical tourists' perceived quality. The results demonstrated that if customers were more likely to be motivated to go to the chosen destination, they had a positive perception towards the quality of medical service providers at the destination. Hypothesis 2 suggested a positive influence of perceived destination image to perceived quality of the medical treatment at the destination. This hypothesized relationship was supported by the equivalent estimate of of $0.373(p<0.001)$ showing that individuals with higher perception towards the image of the chosen destination tend to perceive higher quality of medical procedures at the medical facilities. In addition, compared to motivational factors, the perceived destination image has more significant impact on perceived quality with higher value of standardized path coefficient. This means that between two variables, destination image is a stronger predictor of medical tourists' perceived quality. Hypothesis 3 indicated that perceived quality positively influences medical tourists ' overall satisfaction at the medical destination. This proposed relationship was supported by the equivalent estimate of $.170(\mathrm{p}<.005)$ showing that perceived quality significantly influenced customer's overall satisfaction. The result supported the notion that medical tourists with positive perception of service quality of medical facilities and chosen destination were more likely to be satisfied. There is no significant interaction effect between motivational factor and perceived destination image, only direct effects of independent variables on dependent variables were taken into consideration. The findings of this study reveals that shorter waiting time has the most significant impact on the motivation factors with medical tourists when choosing the destination. This result was also supported from previous literature (Connell, 2007; Ormond, 2011; Hall, 2011). Other than that, cost was also found as the main driver of medical tourists' motivational factor with a relatively high estimated value (0.748). Within the destination image factor, all five observed variables present a significant impact with high factor loadings, wherein the third item "variety of existing tourist attractions for recuperating patients" appears to be the most important. All the results were presented in the SEM model. While there is no significant correlation found between two independent variables, direct effects were pointed out between observed and latent variables in this study. Previous literature showed a strong relationship between motivational factor and perceived quality (Yoon \& Uysal, 2005, Crooks et al., 2002). Tourists that are highly motivated to travel to the chosen destination might perceive the service quality higher that who are not. In terms of the relationship between destination image and perceived quality of medical tourists, the result indicated that destination image had a positively significant influence on perceived quality. Similarly, Bigne et al. (2001) concluded that destination image is a direct antecedent of perceived service quality. The finding of this study also supported the previous literature indicated that destination image creates a positive influence on perceived quality and satisfaction, because it forms expectations that individuals have before the trips (Phelps, 1986, Bigne et al, 2001). Previous literature indicated a strong impact of perceived service quality on overall customer satisfaction. The result of this study also supported that positive influence. When medical tourists perceived the high quality of medical staff, they are likely to be more satisfied with not only the provided service but also with the chosen destination itself.

\section{References}

- Ackerman, S. (2010). Plastic paradise: transforming bodies and selves in Costa Rica's cosmetic surgery tourism industry. Medical Anthropology, 29, 403e423.

- Al-Hinai, S., Al-Busaidi, A., \& Al-Busaidi, I. (2011). Medical tourism abroad. A new challenge to Oman's health system e Al Dakhilya region experience. Sultan Qabus University Medical Journal, 11, 477e484.

- Alleman, B., Luger, T., Reisinger, H., Martin, R., Horowitz, M., \& Cram, P. (2011). Medical tourism services available to residents of the United States. Journal of General Internal Medicine, 26, $492 \mathrm{e} 497$.

- Alsharif, M., Labonté, R., \& Zuxun, L. (2010). Patients beyond borders: a study of medical tourists in four countries. Global Social Policy, 10, 315e335.

- Anon. (2009). MTA releases first patient surveys on medical tourism. Medical Tourism Magazine, 10, 34e36.

- Augé, M. (1995). Non-places. London: Verso.

- Bagheri, A. (2010). Global health regulations should distinguish between medical tourism and transplant tourism. Global Social Policy, 10, $295 \mathrm{e} 297$.

- Basu, P. (2004). My own island home. The Orkney homecoming. Journal of Material Culture, 9, $27 \mathrm{e} 42$.

- Bookman, M., \& Bookman, K. (2007). Medical tourism in developing countries. Basingstoke: Palgrave Macmillan.

- Brown, H. (2008). Do Mexican immigrants substitute health care in Mexico for health insurance in the United States? The role of distance. Social Science and Medicine, 67, 2036e2042.

- Buzinde, C., \& Yarnal, C. (2012). Therapeutic landscapes and postcolonial theory: a theoretical approach to medical tourism. Social Science and Medicine, 74, $783 \mathrm{e} 787$. 
- Carrera, P., \& Bridges, J. (2006). Globalization and healthcare: understanding health and medical tourism. Expert Review of Pharmacoeconomics and Outcomes Research, 6, 447e454.

- Chee, H. (2010). Medical tourism and the state in Malaysia and Singapore. Global Social Policy, 10, $336 \mathrm{e} 357$.

- Cohen, E. (2008). Medical tourism in Thailand. In E. Cohen (Ed.), Explorations in Thai tourism (pp. 225e255).

Bingley: Emerald.

- Connell, J. (2006). Medical tourism: sea, sun, sand and .. surgery. TourismManagement, 27, 1093e1100.

- Connell, J. (2008). Tummy tucks and the Taj Mahal? Medical tourism and theglobalization of health care. In A.

Woodside, \& D. Martin (Eds.), Tourism management (pp. 232e244). Wallingford: CABI.

- Connell, J. (2011b). A new inequality? Privatisation, urban bias, migration and medical tourism. Asia Pacific Viewpoint, 52, 260e271.

- Cook, P. (2010). Constructions and experiences of authenticity in medical tourism: the performances of places, spaces, practices, objects and bodies. Tourist Studies, 10, 135e153.

- Crooks, V., Turner, L., Snyder, J., Johnston, R., \& Kingsbury, P. (2011). Promoting medical tourism to India: messages, images, and the marketing of international patient travel. Social Science and Medicine, 72, $726 \mathrm{e} 732$.

- Dalstrom, M. (2012). Winter Texans and the re-creation of the American medical experience in Mexico. Medical Anthropology, 31, 162e177.

- Deloitte. (2009). Medical tourism: Update and implications. Washington D.C.: Deloitte Center for Health Solutions.

- Edelheit, J. (2008). Defining medical tourism or not? Medical Tourism Magazine, 5, 9e10.

- Ehrbeck, T., Guevara, C., \& Mango, P. (2008). Mapping the market for medical tourism. McKinsey Quarterly, May, $1 \mathrm{e} 11$.

- Erbe, B. (2011). 'Maternity tourism' in San Gabriel. Korea Times, 2 April.

- Gilmartin, M., \& White, A. (2010). Interrogating medical tourism: Ireland, abortion and mobility rights. Signs, $36,275 \mathrm{e} 280$.

- Glinos, I., Baeten, R., Helble, M., \& Maarse, H. (2010). A typology of cross-border patient mobility. Health and Place, 16, 1145e1155.

- Goodrich, J., \& Goodrich, G. (1987). Health-care tourism e an exploratory study. Tourism Management, 8, $217 \mathrm{e} 222$

- Gupta, A. (2008). Medical tourism in India: winners and losers. Indian Journal of Medical Ethics, 1, 4e5.

- Helble, M. (2011). The movement of patients across borders: challenges and opportunities for public health. Bulletin of the World Health Organisation, 89, 68e 72.

- Heung, V., Kucukusta, D., \& Song, H. (2010). A conceptual model of medical tourism: implications for future research. Journal of Travel and Tourism Marketing, 27, 236e251.

- Higginbotham, G. (2011). Assisted-suicide tourism: is it tourism? Tourismos: An International Multidisciplinary Journal of Tourism, 6, 177e185.

- Hopkins, L., Labonté, R., Runnels, V., \& Packer, C. (2010). Medical tourism today: what is the state of existing knowledge? Journal of Public Health Policy, 31, 185e198.

- Horowitz, M., \& Rosensweig, J. (2008). Medical tourism vs. traditional international medical travel: a tale of two models. International Medical Travel Journal, 3, 30e33.

- Horton, S., \& Cole, S. (2011). Medical returns: seeking health care in Mexico. Social Science and Medicine, 72 , $1846 \mathrm{e} 1852$.

- Hunter, D., \& Oultram, S. (2010). The ethical and policy implications of rogue medical tourism. Global Social Policy, 10, 297e299.

- Inhorn, M., \& Patrizio, P. (2009). Rethinking "reproductive tourism" as "reproductive exile". Fertility and Sterility, 29, 904e906.

- Jenner, E. (2008). Unsettled borders of care: medical tourism as a new dimension in America's health care crisis. Research in the Sociology of Health Care, 26, $235 \mathrm{e} 249$.

- Jones, M. (2011). Clinics of oblivion: makeover culture and cosmetic surgery tourism, portal. Journal of Multidisciplinary International Studies, 8(2), 1e17, (online).

- Kangas, B. (2007). Hope from abroad in the international medical travel of Yemeni patients. Anthropology and Medicine, 14, 293e305.

- Kangas, B. (2011). Complicating common ideas about medical tourism: gender. Class and globality in Yemenis' international medical travel. Signs, 36, 327e332.

- Knudsen, B. (2011). Thanatourism: witnessing difficult pasts. Tourist Studies, 11, 55e72.

- Laugesen, M., \& Vargas-Bustamante, A. (2010). A patient mobility framework that travels: European and United-States Mexican comparisons. Health Policy, 97, 225e231.

- Lee, M., Han, H., \& Lockyer, T. (2012). Medical tourism e attracting Japanese tourists for medical tourism experience. Journal of Travel and Tourism Marketing, 29, 69e86.

- Lefebvre, B. (2008). The Indian corporate hospitals: touching middle class lives. In C. Jaffelot, \& P. van de 
Veer (Eds.), Patterns of middle class consumption in India and China (pp. 88e109). New Delhi: Sage.

- Lunt, N., \& Carrera, P. (2010). Medical tourism: assessing the evidence on treatment abroad. Maturitas, 66, 27e32.

- Moghimehfar, F., \& Nasr-Esfahani, M. (2011). Decisive factors in medical tourism destinations choice: a case study of Isfahan, Iran and fertility treatments. Tourism Management, 32, 1431e1434.

- NaRanong, A., \& NaRanong, V. (2011). The effects of medical tourism: Thailand's experience. Bulletin of the World Health Organisation, 89, 336e344.

- Parry, B. (2008). Entangled exchange: reconceptualising the characterisation and practice of bodily commodification. Geoforum, 39, 1133e1144.

- Pollard, K. (2010). Medical tourism statistics: Comparing apples with apples. http://treatmentabroad.blogspot.com/2010/03/medical-tourism-statistics-comaaring. html.

- Reisman, D. (2010). Health tourism. Social welfare through international trade. Cheltenham: Edward Elgar.

- Sengupta, A. (2011). Medical tourism: reverse subsidy for the elite. Signs, 36, 312e319. Smith, P., \& Forgione, D. (2007). Global outsourcing of healthcare: a medical tourism model. Journal of Information Technology Case and Application Research, 9(3), 19e30.

- Thompson, C. (2011). Medical migrations afterword: science as a vacation? Body and Society, 17, $205 \mathrm{e} 213$.

- Veerasoontorn, R., Beise-Zee, \& Sivayathorn, A. (2011). Service quality as a key driver of medical tourism: the case of Bumrungrad International Hospital in Thailand. International Journal of Leisure and Tourism Marketing, 2, 140e158.

- Wilson, A. (2011). Foreign bodies and national scales: medical tourism in Thailand. Body and Society, 17 , $121 \mathrm{e} 137$. 